\title{
Designing cropping systems from nature
}

\author{
Eric Malézieux
}

Accepted: 5 October 2010 /Published online: 1 June 2011

(C) The Author(s) 2011. This article is published with open access at Springerlink.com

\begin{abstract}
Despite huge gains in productivity, environmental impacts of industrial agriculture based on a few high-yielding crop cultivars and the massive use of chemical fertilisers and pesticides have led to a search for new pathways leading to more sustainable agriculture in both temperate and tropical regions. New strategies incorporating ecological knowledge gained from the observation of natural ecosystems is an alternative to design "ecologically intensive" agroecosystems. Such systems are indeed both ecological and productive. Designing ecologically intensive agroecosystems calls for indepth knowledge of biological regulations in ecosystems, and for the integration of traditional agricultural knowledge held by local farmers. This article reviews the main initiatives underlying ecologically intensive agroecosystems, analyses basic concepts, and proposes a framework for action. The rainforest model, the dry forest model, and the American Prairie are exemplified as three main natural systems at the basis of the mimicry concept. The link between biodiversity and the mimicry hypotheses, and the use of the concepts of productivity, efficiency, stability, and resilience for agroecosystems are discussed. Six main principles for cropping system design based on natural ecosystem mimicry are identified. A three-step framework for action is proposed, including nature observation, experimental design, and participatory design. Although far from being a panacea, the mimicry approach can provide new ways for agroecosystem design both in temperate and tropical countries.
\end{abstract}

Keywords Agroecology Ecological intensification . Biological regulations in agroecosystems $\cdot$ Sustainable agriculture

\section{E. Malézieux $(\bowtie)$}

CIRAD, UR HortSys,

TA-B 103/PS4-Boulevard de la Lironde,

34398 Montpellier Cedex 5, France

e-mail:malezieux@cirad.fr
Contents

1. Introduction: modern agriculture and the need for new

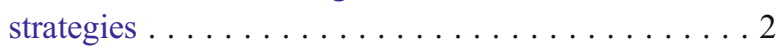

1.1. The impasse of "modern" agriculture . . . . . . . . . 2

1.2. The need for new strategies ............ 2

1.3. Traditional agricultures as a mimic of nature ...... 3

2. Natural ecosystem mimicry and the use of ecological concepts in agriculture . . . . . . . . . . 4

2.1. Natural system models at the basis of mimicry . . . . 4 4

2.1.1. The rainforest model . . . . . . . . . . . 4

2.1.2. The dry forest model ............. 5

2.1.3. The prairie model . . . . . . . . . . . 6

2.2. Hypotheses and concepts . . . . . . . . . 6

2.2.1. Biodiversity and the mimicry hypotheses . . . . 6

2.2.2. Productivity, resilience, equilibrium, and

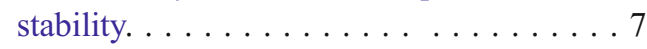

2.2.3. Imposed organisation vs. self-organisation . . . . 8

3. Principles for cropping system design based on natural ecosystem mimicry . . . . . . . . . . . 9

3.1. Use complementary functional traits to ensure production and resilience . . . . . . . . . 9

3.2. Maintain soil fertility through soil cover ........9

3.3. Favour facilitation vs. competition between plants. . . . . . . . . . . . . . 9

3.4. Contain pests through complex trophic levels . . . 10

3.5. Use plant properties and biological alternatives to control pests . . . . . . . . . . . . . 10

3.6. Reproduce ecological successions after disturbance. . . . . . . . . . . . . . 10

4. A framework for action ............. 11

4.1. The three steps . . . . . . . . . . . . 11

4.2. The need for participatory approaches . . . . 12

5. Conclusion .................... 12

6. References ..................... 13 


\section{Introduction: modern agriculture and the need for new strategies}

\subsection{The impasse of "modern" agriculture}

Modern agriculture, on which the world food balance largely relies today, has arisen from the huge progresses made in agronomy but also in genetics and chemistry in the last decades. Modern agrosystems consists of highly simplified ecosystems in which high productivity depends on a few improved high-yielding species and on massive use of chemical inputs and fossil fuels. Today, the great majority of cultivated systems consist of just one storey of genetically and biologically optimised single-species vegetation. Over the last 30 years, this crop specialisation combined with use of chemical inputs, e.g. fertilisers and pesticides, has led to enormous productivity gains worldwide, through the progress of the green revolution. This scheme was until now judged efficient by the predominant paradigms of economic and industrial optimization that aimed at maximising short-term yields and profits (Weiner 2003). It guided the mainstream agricultural development not only in developed countries, but also in certain agricultural sectors in the Tropics, based on exports of a limited number of raw commodities, such as cotton, banana or pineapple, or processed commodities such as palm oil for the world market.

However, an awareness arose in Europe and USA in the 1970s, then rapidly in Africa too, and in most developing countries, of the limitations (mostly environmental but also social) of this intensification model and of the race for productivity through chemical intensification and simplification of the systems (Pimentel et al. 1973; Conway 1998; Griffon 2006). Modern agriculture, characterised by crop specialisation and a massive use of chemicals and energy,

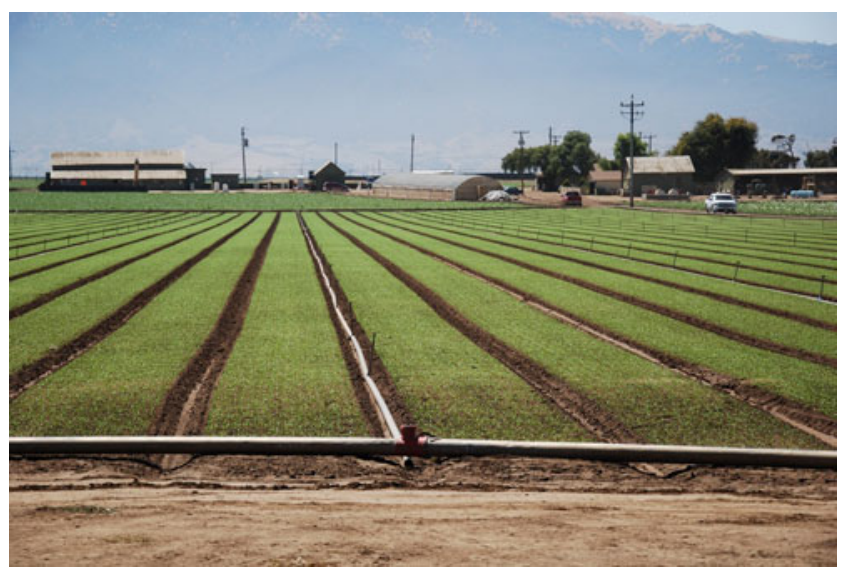

Fig. 1 Horticultural production (salads) in California (USA): despite a high productivity, industrialized systems often generate numerous ecological disservices linked with high quantities of external inputs

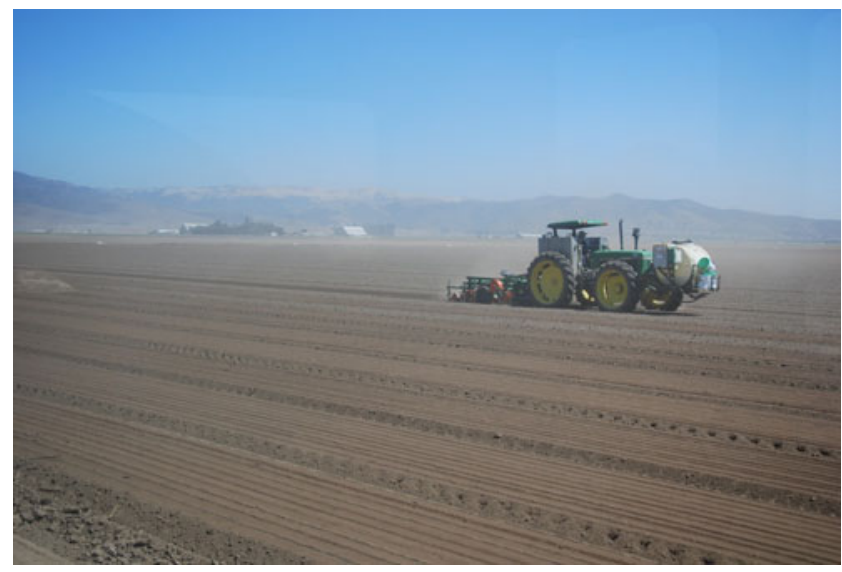

Fig. 2 Horticultural production (salads) in California (USA): despite a high productivity, industrialized systems often generate numerous ecological disservices linked with high quantities of external inputs

has generated and still generates major environmental problems on a local and global scale (Matson et al. 1997; Altieri 1999; Piper 1999; Figs. 1 and 2). Those problems include soil erosion and a reduction in soil quality, loss of biodiversity including loss of local cultivars, disease and pest resistance, deforestation, a reduction in water quality, including contamination of surface and groundwater with nutrients and toxins, high dependency on fossil fuel-based energy, and a major contribution to greenhouse gas emissions. Chemical pesticides can be unsafe for humans and numerous animal species, including effects on non-target species and auxiliaries. Risks for humans include contamination of water and food products, and direct exposure through handling by farmers. Finally, epidemiological evidence of the implication of agricultural chemicals in diseases such as cancers is accumulating throughout the world.

\subsection{The need for new strategies}

From the viewpoint of an evolution of sciences, nature and agriculture has long been the subject of separate paradigms, theories, and models. Ecological engineering defined as "the design of sustainable ecosystems that integrate human society with its natural environment for the benefit of both" (Mitsch 1996) is an attempt to integrate human activities in ecosystems in a sustainable vision. Ecological engineering involves not only the restoration of ecosystems that have been disturbed by human activities, such as environmental pollution, but also the development of new sustainable ecosystems with both human and ecological value (Mitsch and Jorgensen 2003). However, ecological engineering has mainly concentrated on river and wetland restoration, and post-mining landscaping, but hardly on agricultural system design. Ecological engineering considers forest and range- 
land ecosystems, fisheries, and also urban planning and urban horticulture, but has only recently begun to significantly address agriculture.

Increased agricultural pressure on humans and on ecosystems means that it is now necessary to rethink the often unsustainable natural resource management methods used in agriculture (Brown et al. 2000; Tilman et al. 2002). In view of this, the dominant paradigm of intensification is being challenged and new conceptual pathways are being sought to construct sustainable agroecosystems. The framework proposed a few years ago, based on the concept of multifunctional agriculture, highlighted once again the different functions of agriculture, and primarily the environmental roles that agriculture can and must play. Crop diversification on farms is an old issue, but it is still on the agenda and has once again become essential in dealing with the ecological, economic, and social sustainability of agrosystems (Connor 2001). The debate about biodiversity has strengthened and added a further dimension to the issue. For instance, the creation of spaces and habitats for wildlife in agricultural areas has also explicitly become an objective in itself for agriculture (McNeely and Scherr 2003). More generally, interest in incorporating biodiversity into agricultural systems and in ways of exploiting ecosystem services has grown (Gross and Smith 2002; Swift et al. 2004; Clergue et al. 2005; Jackson et al. 2005) and can create the basis for constructing new cropping systems (Vandermeer 1995; Malézieux et al. 2009). Sustainable agriculture should ensure no chemical contamination of the environment, no soil loss, a limited impact on wild biodiversity, and reduced dependency on non-renewable resources (energy, water), while of course meeting economic and social objectives. How can one design agricultural systems that respond to the objectives of productivity and ecosystem services?

Agroecologists, i.e. scientists in the field of agroecology (Wesel et al. 2009), have suggested that natural ecosystems may provide appropriate models for both environmental and social objectives, while providing long-term sustainability. This "mimic" approach is based on the premise that the structure and/or functioning of natural ecosystems can be a model to mimic for the conception of agricultural systems. It puts forward the hypothesis that it is possible to build sustainable agroecosystems based on the imitation of natural communities (Lefroy et al. 1999). This idea is based on the paradigm whereby natural ecosystems are sustainable and adapted to local constraints (Dawson and Fry 1998). With the sun and water from rainfall as energy sources, natural ecosystems allow soil and biodiversity conservation and high resilience. By incorporating certain characteristics of natural ecosystems into cultivated agrosystems, it can be hoped to confer upon them certain worthwhile properties, such as productivity (Fukai 1993), stability (Aerts 1999; Schulte et al. 2002), resilience, notably with regard to pest attacks
(Trenbath 1993), energy efficiency in a context of depleted fossil fuels (Hatfield 1997) and, ultimately, sustainability. It is especially possible to seek compromises between these different properties. Hence, designing agricultural systems "in Nature's image" has become a realistic objective for sustainable agriculture (Dawson and Fry 1998). Natural and cultivated ecosystems (both "traditional" and "modern") are characterised by major differences in terms of structure, functioning, and services (Table 1). However, despite their differences, natural and cultivated ecosystems involve the same biophysical and biological processes and resources: solar energy, water, soil, and living organisms are at the basis of biomass production. The prime aim of agriculture is to manage those resources in order to obtain products of use to mankind. In theory, only the aspects linked to anthropization and the associated socio-economic and cognitive resources (work, capital, practices, knowledge, information, etc.) define the essential difference between natural and cultivated ecosystems. More recently, the framework of ecoagriculture proposed by McNeely and Scherr (2003), based on understanding and practising ecological synergies between farming and natural systems management was applied to agricultural landscapes. Ecoagriculture places biodiversity at the heart of its strategies both (1) to conserve and restore ecosystem services and increase wild populations in agroecosystems and (2) to enhance agricultural production systems. Mimicking natural ecosystems becomes a means of creating and enhancing suitable habitat niches for wildlife.

\subsection{Traditional agricultures as a mimic of nature}

Even today, traditional farming systems in the Tropics account for a major share of world agriculture and are far from being marginal situations. Indeed, although it has been largely developed worldwide in the past 50 years, "modern" intensive agriculture with its high energy, mineral fertiliser, and pesticide consumption only involves a marginal fringe of the populations in developing countries. Most farmers in the South (over a billion) still remain today on the sidelines of modern intensive agriculture technologies. Around $80 \%$ of farmers in Africa and $40-60 \%$ of those in Latin America and Asia still work today solely with manual tools, and only 15 $30 \%$ of them have access to draught animals (Mazoyer and Roudart 1997). This just goes to show how important traditional cropping systems, including slash-and-burn agriculture common since Neolithic times and still widely practised today, are in the world food balance even today. Shifting cultivation has long been accused of contributing to global deforestation and much research work has been devoted to finding alternatives to it rather than improving it. Certainly, as Rice (2003) pointed out, the prevailing opinion that shifting agriculture is negative needs to be rethought: its role in direct deforestation remains lower than 
Table 1 Characteristics of natural ecosystems, traditional, and modern agriculture

\begin{tabular}{|c|c|c|c|}
\hline & Natural ecosystems & Traditional agriculture & Modern agriculture \\
\hline Species richness & High & Medium & Low \\
\hline On a plot scale & $\begin{array}{l}\text { One ha of tropical forest } \\
\text { contains more than } 100 \\
\text { tree species }\end{array}$ & $\begin{array}{l}\text { Most cropping systems include } \\
\text { several plant species }\end{array}$ & $\begin{array}{l}\text { Most cropping systems have } \\
\text { a sole crop }\end{array}$ \\
\hline On a global scale & & $\begin{array}{l}\text { Traditional agriculture is based } \\
\text { on many species and cultivars } \\
\text { including native species }\end{array}$ & $\begin{array}{l}\text { World industrial agriculture } \\
\text { is based on fewer than } 70 \\
\text { species }\end{array}$ \\
\hline Structure & Complex_variable & Complex & Simple - often monocanopy \\
\hline \multirow[t]{2}{*}{ Dispersion of seeds } & Natural & - & Controlled \\
\hline & & & $\begin{array}{l}\text { Mechanical seed-bed } \\
\text { preparation }\end{array}$ \\
\hline Plant evolution and selection & Natural & Selection & Breeding, biotechnology \\
\hline Soil cover & Permanent & Variable & Non-permanent \\
\hline $\begin{array}{l}\text { Simultaneous presence of } \\
\text { perennials and non-perennials }\end{array}$ & Frequent & Frequent & Rare \\
\hline Life form richness & High & Variable & Low \\
\hline Productivity & Variable & Variable & High \\
\hline Use of external chemicals & - & Low & High \\
\hline $\begin{array}{l}\text { Population control of plants } \\
\text { and animals }\end{array}$ & Natural & Use of natural processes & Use of pesticides \\
\hline Use of fossil energy & - & Low & High \\
\hline Exports $(\mathrm{C}$, minerals $)$ & Low & Low & High \\
\hline Nutrient sources & Recycling & Recycling, organic & Chemicals \\
\hline Nutrient loss & Low & Low & High \\
\hline Resilience & High & Medium & Low \\
\hline
\end{tabular}

has often been suggested and the way resources are used in slash-and-burn agriculture needs more research. In other situations in the Tropics, undestroyed forest is usually gradually domesticated, leading to productive agroforests based on a high level of biodiversity (Joshi et al. 2003).

Traditional agricultural systems, which are a product of numerous generations of subsistence farmers in the Tropics, are often the result of a long observation of nature and may be an important source of ideas for designing cropping systems (Martin et al. 2010). Slash-and-burn systems reproduce nature's behaviour after fire, agroforestry systems in the humid Tropics reproduce a rainforest structure and functioning. Paradoxically, might these traditional systems based on integrated management of local natural resources and, in many cases, on rational biodiversity management, which were long ignored or disparaged, constitute models for the cropping systems of tomorrow? That is the hypothesis put forward today by some agronomists (Ewel 1999; Altieri 2002; Jackson 2002; Vandermeer 2003). Although the field of agroecology may consider different meanings and scales (Wesel et al. 2009), the sciences of agroecology (Altieri 1995, 2002; Dalgaard et al. 2003; Francis et al. 2003; Gliessman 2007), and landscape ecology (Forman
1995) propose today to embrace ecological and farmers' knowledge in agroecosystem design.

What are the scientific foundations of the design paradigm based on the "mimicry" of natural ecosystems? Is mimicry of natural ecosystems a realistic hypothesis for building innovative cropping systems? The following sections examine (1) the main natural system models at the basis of mimicry and the concepts that lie behind existing solutions, (2) states the main principles for natural system mimic, and (3) proposes a framework for action.

\section{Natural ecosystem mimicry and the use of ecological concepts in agriculture}

Although the concept of mimicry is not dependant on a specific kind of ecosystem, some ecosystems were more often used for testing the mimicry hypotheses. Main natural systems used as models for agriculture include the rainforest ecosystem, the dry tropical forest model and the American prairie. We examine in the following how these three ecosystems serve as models and then how concepts defined for natural systems can be applicable to agricultural systems. 


\subsection{Natural system models at the basis of mimicry}

\subsubsection{The rainforest model}

One of the main natural models underlying the mimicry theory is the rainforest model proposed by Ewel (1986) for the humid Tropics. According to Ewel (1999), humid tropical ecosystems appear to be particularly suitable for application of the "mimicry of Nature" concept. The tropical rainforest that combine multiple strata, incorporate a high specific diversity constitute a model for agroforestry systems. Agroforestry systems combine annual and perennial, herbaceous and woody species, in a complex system in terms of the number of plant species, biological interactions, and practices (Torquebiau 2007). Widespread in Asia, Oceania, Africa, and Latin America, they ensure both subsistence for local populations and major environmental and socio-economic services (Sanchez 1995; Nair 2001; Schroth et al. 2001, 2004; Figs. 3, 4, and 5). These agroforests contain many useful species and reach states and structures close to those of the original natural forest ecosystems. Yet the latter take more than half a century to develop, after gradual management involving several successive phases. It is by gradually reconstructing a suitable environment adapted to the biology of the different plants that it has been possible to exploit the different useful species. Regarding biodiversity, agroforests reach levels that can be compared in some cases to those found in nearby natural forests (comparison of the number of species present out of the major biological groups: trees, shrubs, creepers, herbaceous plants, epiphytes). The same applies to animal biodiversity (Perfecto et al. 1996; Leakey 1999; Perfecto and Armbrecht 2003).

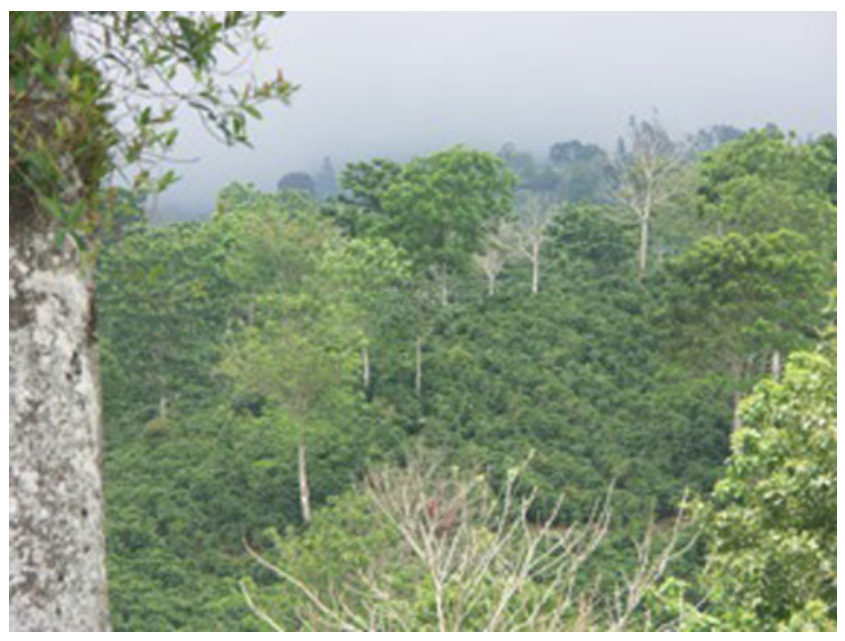

Fig. 3 Coffee agroforestry systems in Costa Rica provide ecological services regarding soil conservation, water quality, and carbon sequestration

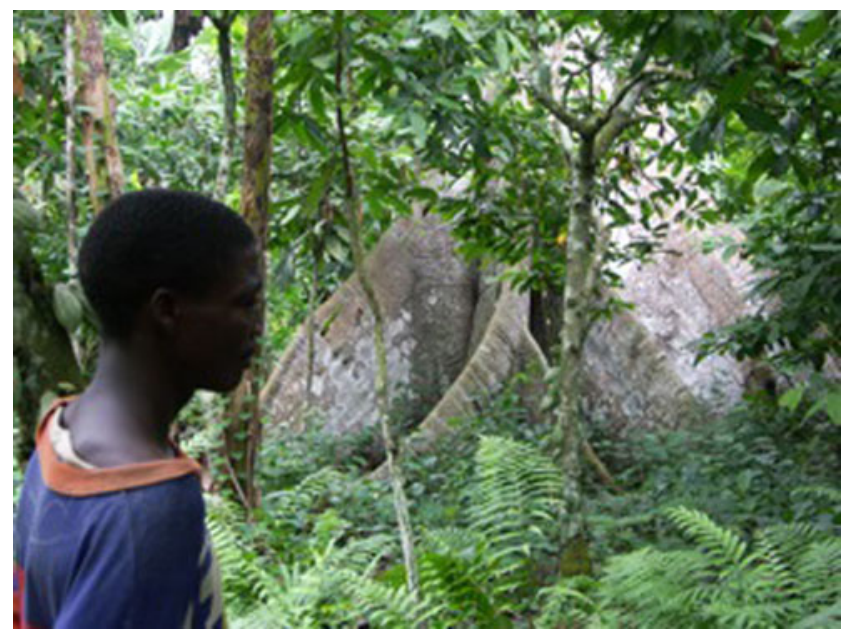

Fig. 4 Beyond significant cocoa production, Cocoa agroforestry systems in Cameroun provide wood, fruits, medicine and a variety of ecological services

Such properties can be found in the humid tropical zones of Asia, Africa, and Latin America, thereby affording generic properties to complex agroforestry systems. Some functions, such as maintaining biological diversity, maintaining biomass storage potential, and maintaining potential for the regulation of major biogeochemical fluxes, play an overall ecological regulator role. These agroforestry systems stand out from specialised cropping systems through three essential aspects arising from natural ecosystems: (1) their functioning is based on relations between species (competition, facilitation), (2) they offer high constituent biodiversity, and (3) they produce a multiplicity of products and environmental services that monocultures do not offer.

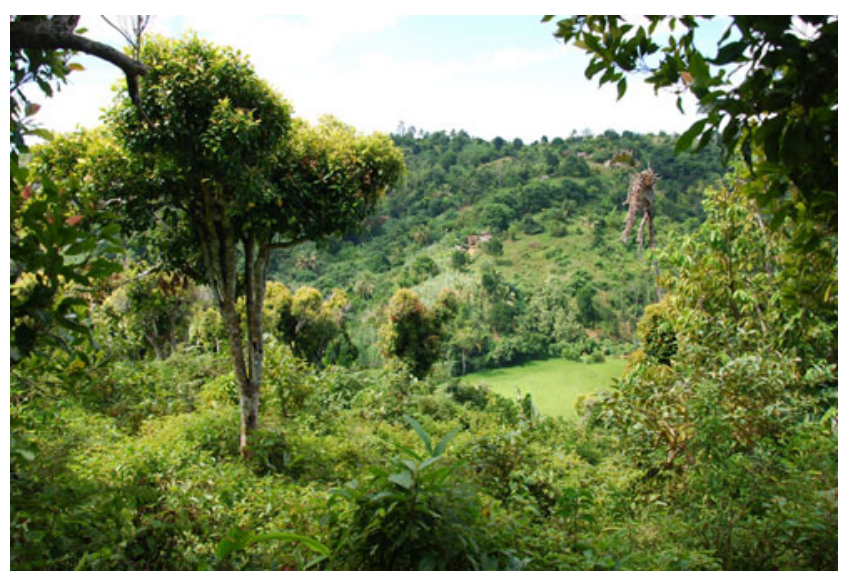

Fig. 5 Agroforestry landscape in Madagascar. Forest-like ecosystems made of high value fruit trees (litchees, clove trees) have resilient properties in response to extreme events (such as cyclones) 


\subsubsection{The dry forest model}

Mimicry principles can be applied not only to the humid tropics but also to other agroecological areas such as the sub-humid and semi-arid tropics. Van Noordwijk and Ong (1999) considered the savannah zone where ecosystems are characterised by strong seasonality related to water stress and where natural vegetation is a continuous vegetation dominated by $\mathrm{C} 4$ grasses and scattered trees and shrubs. Agrosystems in that zone include agroforestry systems where food crops replace understorey grass and where many of the mature original trees are kept, thereby maintaining overall natural ecosystem functioning. The authors reported that attempts to improve the productivity of this system with fast-growing leguminous trees often failed due to greater competition for water with food crops. The traditional system often includes fallow-crop rotations, where the density of shrubs and tree biomass increases during the fallow phase and is maintained at a low level during the crop phase. Above-ground tree density in these parklands may be low but tree roots are in fact shown to exploit all the land area through large root extension.

Another example of savannah-like agroecosystems is given by Joffre et al. (1999) in the Mediterranean climate of the southwestern Iberian Peninsula. The dehesa system is a typical savannah-like agroforestry system characterised by an open tree layer, mainly dominated by Mediterranean evergreen oaks, and an herbaceous layercomposed of either cultivated cereals such as oats or wheat, or more commonly native annual species used as grazing resources. In this several millennia-old system, trees are planted, pruned, and harvested and are an integrated part of the system. The stability of this dehesa system has been shown to be highly dependent on water resources, nutrient availability, and human management in a long-term perspective. Tree density, a major indicator of the structure of the ecosystem and the result of long-term management by farmers, is greatly linked to mean annual rainfall, corresponding to an optimum functional equilibrium based on the hydrological balance.

\subsubsection{The prairie model}

Natural grassland ecosystems may be another model for agriculture: based on plant biodiversity, they protect the soil, provide their own nitrogen requirements, and are resilient to pests and diseases. According to Piper (1999), agricultural systems designed as structural and functional analogues of prairie plant communities can be productive and resilient. It becomes possible to conceive polycultures of perennial grain plants whose species composition should include perennial $\mathrm{C} 3$ and $\mathrm{C} 4$ grasses, nitrogen-fixing species, and composites. Such perennial polycultures of grains, in mimicry of the American Prairie, will require new crop species, selected according to new criteria other than those used for intensive industrial agriculture.

These three mimicry models highlight the critical importance of biodiversity in the mimicry concept. Beyond the "models" represented by humid and dry forest ecosystems and by prairie ecosystems, it is now important to indicate the main hypotheses at the basis of the mimicry theory and identify the ecology concepts that can be used to design sustainable cropping systems.

\subsection{Hypotheses and concepts}

\subsubsection{Biodiversity and the mimicry hypotheses}

The role of biological diversity in natural ecosystem functioning has been and remains the subject of much work in the community of ecologists. A great deal of recent work has shown some positive correlations between biodiversity and primary productivity, nutrient retention and post-stress resilience in natural ecosystems (Hector et al. 1999; Loreau et al. 2001), but also in cultivated ecosystems (Altieri 1999). Since Darwin, the hypothesis that the stability and sustainability of ecosystems rely on their biological diversity has appeared in numerous studies (and debates) involving ecologists. Tilman et al. (1996) assessed the sustainability of numerous prairie ecosystems characterised by different levels of biological diversity (number of plant species present). The fact that sustainability indicators, such as the degree of mineral nutrient recycling but also productivity, increase in line with biological diversity confirms the general opinion, but especially opens up new interesting prospects for prairie management, as shown by Piper (1999). In reality, the general hypothesis that a complex community is more stable than a community consisting of a limited number of species largely remains to be confirmed and any such confirmation seems to depend on a large number of factors. Vitousek and Hooper (1993) showed that the relation between the number of species in an ecosystem and the functions ensured by that ecosystem, e.g. primary productivity, is usually of an asymptotic nature: a relatively small number of species is likely to reach a high level of efficiency for the function in question.

While the actual number or species is no guarantee of stability, most authors agree in acknowledging the importance of functional diversity (Silver et al. 1996; Hooper et al. 2005) in the stability and resilience of ecosystems. For Gunderson and Holling (2002), the very definition of resilience incorporates the notion of functional sustainability, e.g. maintaining the integrity of functions, much more than that of structural sustainability, e.g. maintaining the integrity of species. 
Consideration of heterogeneity as a potential source of stability is more recent in ecology. The idea has been developing relatively recently with the development of landscape ecology ( $\mathrm{Wu}$ and Loucks 1995). It is thus possible to consider heterogeneous ecosystems, formed by patchworks of ecosystems subjected to recurrent disturbances like fire, as stable.

Ecosystems with greater diversity are more likely to contain multiple interactions and feedback loops associated with more complex food webs: this may be of great interest for agroecosystem resilience. Some authors call for the conservation of all the species in the system, as the elimination of species may compromise the integrity of the system. Beyond the fact that it is certainly unrealistic to conserve all species in a mimicry approach, this should focus our attention on the need to identify redundant species for identified functional groups, so as to conserve the function through identified species.

Another argument for maximising biodiversity in ecosystems is that ecosystems with greater diversity are more likely to contain the most productive species. This is probably true for natural ecosystems but it is of little interest for agroecosystems, as productive species are chosen by farmers.

Positive correlations between biodiversity and productivity, nutrient retention, and post-stress resilience have also been found in cultivated ecosystems (Altieri 1999; Malézieux et al. 2009). What biological diversity should therefore be chosen to optimise these different factors within cropping systems? Ewel (1999) and Van Noordwijk and Ong (1999) proposed two mimicry hypotheses for designing agrosystems from natural ecosystems:

- The first hypothesis argues that agrosystems should mimic the structure and function of natural ecosystems existing in a given pedoclimatic zone. It is based on the principle that the structure of natural ecosystems in a given area results from natural selection and therefore has a major ability to adapt and adjust to disturbances. Arguing that natural selection mainly acts on the level of genes, individual and family groups, Denison et al. (2003) criticised the validity of the first hypothesis and considered there is no reason to expect the structure of natural ecosystems to be a relevant source of inspiration for improving agriculture. This is, of course, an important and fundamental point of controversy.

- The second hypothesis argues that agrosystems should mimic the diversity of species existing in natural ecosystems too, hence maintaining the diversity existing in the natural ecosystems in a given zone. In the long debate on the relationship between agriculture and biodiversity, and more precisely in the debate on segregation vs. integration strategies for conservation, the second mimicry hypothesis clearly benefits the integration strategy that consists in maximising diversity in agricultural systems.
In their attempt to define ecological engineering, Bergen et al. (2001) identified five main principles. Most of these principles might be considered of great interest for cropping system design, although they were not defined for that purpose. The first principle promotes a design based on the "mimicry of natural structures and processes". It emphasises selforganisation in ecosystems based on complexity and diversity. The second principle is based on the site-specific aspect as opposed to standardised solutions. Both principles may be considered at the basis of the "mimicry theory" in agriculture.

\subsubsection{Productivity, resilience, equilibrium, and stability}

The concepts of production, efficiency, stability and resilience, as defined by Holling (1973), lie at the heart of natural ecosystem characterization by ecologists. They were proposed by Fresco and Kroonenberg (1992) to assess agrosystems, but in reality their use remains very limited.

The production (or productivity) concept is a concept familiar to agronomists, although it is often used to consider useful yield, whereas it is first and foremost the primary productivity of the ecosystem that ecologists are interested in. This difference in objective and time step for assessing ecosystems is very important since it involves the very principle of agriculture, which consists in increasing the "take-off" of materials of use to mankind. Can mimicry of natural ecosystems provide the yields expected from modern agriculture? Few studies provide answers to this question but Ewel (1999) suggested this will hardly be the case for two main reasons. Firstly, only a small share of biomass is harvested from natural ecosystems. Agroforestry systems are characterised by high carbon investment in structure but only a fraction can be exported. Secondly, most ecosystems are characterised by a trade-off between reproduction, e.g. carbon dedicated to seeds, and permanence, e.g. carbon dedicated to structure, that do not allow high seed harvests. As already noted by Ewel (1986), if the benefit of nature-like ecosystems is low risk, their limitation may be low yield. Annual crops often have higher net primary productivity than perennial crops, and much of that productivity is allocated to the reproductive or storage organs harvested for food. Conversely, the energy allocated to structure in perennials and the small amount of biomass harvested determines low yields but allow ecological functions to be maintained. Hence, perennial polycultures built on nature mimicry may be sustainable cropping systems for the future, but they still have biological constraints in term of productivity. Although this may remain true from a carbon balance point of view, the mimicry system can be efficient if we consider the nutritional, economic, and social value of the various products exported from complex mimicry agrosystems: addition of the masses of the various products extracted 
from mimicry agroforestry systems has a limited interest compared to the social benefits of medicine, spices, fruits, tubers, wood, etc. extracted from the agrosystem.

Resilience is a property of major interest for ecologists who are interested in natural ecosystems. The resilience concept is therefore widely used today in ecology, but sometimes with different senses. Resilience is defined as the ability of an ecosystem to reorganise itself and restore its initial structure and functioning after a disturbance. This is a major ecological characteristic, which reflects the nature and complexity of the homeostatic processes in an ecosystem. Westman (1978) specifies that the resilience of an ecosystem can be characterised by its elasticity (time needed for restoration), its amplitude (degree of modification reached before restoration), its hysteresis (varying degree of asymmetry in alteration and restoration paths) and its malleability (capacity of the ecosystem to undergo frequent modifications). More recently, Walker et al. (2004) proposed other attributes for ecosystem resilience: latitude (deformation limit beyond which a return to the initial state is impossible), resistance (varying degree of a system's ability to change), precarity (closeness of the current state of the system to a "point of no return"), and panarchy (dependency of the system in relation to hazards and factors outside the system). Other ecosystem attributes have also been defined, such as inertia which is the capacity of an ecosystem to resist a change in its structure and its function after a disturbance. Some are essential for analysing, in particular, the evolution of ecosystems inhabited by humans, such as adaptability and transformability (Walker et al. 2004). For instance, adaptability is defined as the ability of players in a system to influence resilience. Transformability corresponds to the ability to create a new system when ecological, economic, and social conditions have become unbearable. What are the sense and relevance of the attributes inertia, resilience, adaptability, and transformability when applied to cropping systems and to agricultural systems in general? Do these attributes enable a better characterization of this concept and the way it should be approached and used? How does the level of biodiversity affect resilience and inertia? These questions are increasingly vital within the agricultural research community. For example, one can thus consider that Sahelian cropping systems, which are based on the exclusive cultivation of millet (the only plant adapted to the ecological environment), have low resilience (low amplitude in relation to the absence of choice, great precarity, for example, in relation to a drop in rainfall), low adaptability, and low transformability (no alternative options). The duration of fallow needed to maintain yields in slash-and-burn cropping systems is another possible application: What is the possible amplitude of the system? What is its elasticity? An attempt can thus be made to generalise the use of these attributes for cropping systems. A cropping system can be in a situation of precarity (close to a state of no return), easy to modify (low resistance), highly dependent on the outside (panarchy), adaptable, transformable, or not very transformable. For example, intensive monocultures can be considered precarious and not very adaptable (insofar as, for example, parasite control is based exclusively on pesticide use), tree crop-based systems are less adaptable and less transformable than annual crop-based systems, etc.

Stability is another controversial attribute. The validity and operationality of many concepts in ecology are being discussed today within the actual community of ecologists itself (O'Neill 2001). The very definition of the "natural" vegetation of an ecosystem is the subject of debates, or even controversies in ecology (Sprugel 1991). It is considered today that most natural ecosystems cannot be considered in equilibrium: they are continually evolving in response to a changing environment (under the effect of more or less frequent disturbances, or climate change). In this context, the very concept of natural vegetation no longer has a sense, since we are faced with an ongoing and dynamic recomposition of the vegetation in terms of species. The hypothesis of the existence of a "climax", an optimum state of equilibrium endowed with particular properties of homeostasis is now mostly challenged. If this climax concept is inoperative, it has to be considered that the structure of ecosystems evolves in response to natural disturbances of varying amplitude or frequency (fires, floods, climate changes, etc.). Whereas a frequent and regular disturbance will be a factor of stability for the vegetation, the absence of disturbance gives rise to changes in vegetation structure: other species follow on from the species adapted to the disturbance. Disturbance then becomes a factor of stability for the ecosystem. Thus, since the beginnings of agriculture, mankind has used fire to disturb the ecosystem, thereby mimicking nature. The advantages are numerous for a crop planted after burning: reduced competition for light, thermal destruction of weed seeds, provision of mineral nutrients.

\subsubsection{Imposed organisation vs. self-organisation}

One of the main concepts at the basis of ecological engineering is the self-designing capacity of ecosystems: self-organisation is the property of ecosystems to reorganize themselves given an environment that is inherently unstable and non-homogeneous (Mitsch and Jorgensen 2003). Selforganisation, a property of natural ecosystems, is generally opposite to the imposed organisation of agriculture. If selforganisation develops flexible networks with a high potential for adaptation, would it be possible to take inspiration from self-organisation in natural ecosystems to define an imposed organisation? The ecosystem "designs a 
mix of man-made and ecological components in a pattern that maximises performance, because it reinforces the strongest of alternative pathways that are provided by the variety of species and human initiatives" (Odum 1989).

Today, these notions seem essential for dealing with the long-term evolution of cropping systems, such as slash-andburn agriculture where the cyclically recurring fallow may enable a return to an initial state, or complex agroforestry systems that combine several species over different time steps and in which the species may have varied functions. The evolution of a cropping system involves all the stands that compose it, i.e. all the biological objects composing the biocoenosis: cultivated and uncultivated plants, animal communities, soil microflora, etc. How are colonisation, competition, predation, mutualism, and extinction processes involved in that succession? How do human interventions, in their turn, act in these processes to control that evolution? It is possible, with natural ecosystems, to see autogenous successions that correspond to successions governed by internal processes (e.g. when there is a reduction in organic matter in the soil that leads to a change in the biocoenosis) and allogenous successions (when the successions are governed by outside processes), and such distinctions remain relevant when dealing with successions in cropping systems.

\section{Principles for cropping system design based on natural ecosystem mimicry}

Cropping system designs based on natural ecosystem mimicry require a set of diverse observations of natural ecosystems and traditional agrosystems, but also call for the integration of concepts from both ecology and agronomy and their application to agricultural systems. In addition to the strict mimicry of natural ecosystem structure and functioning, we believe that the "natural ecosystem mimicry" approach for cropping system design also calls for the definition and application of principles to guide the approach. These principles can be applied on different scales and levels of organisation (Fig. 6). All the observations, axioms, and proposals by authors on natural ecosystem mimicry are combined here and synthesised into six principles.

\subsection{Use complementary functional traits to ensure} production and resilience

The different use of resources by different species forms the basis of the ecological niche concept. Phenology may also be an efficient way of facilitating access to complementary resources. It is the mix of life forms not the mix of species that exerts major controls over ecosystems (Ewel 1986).

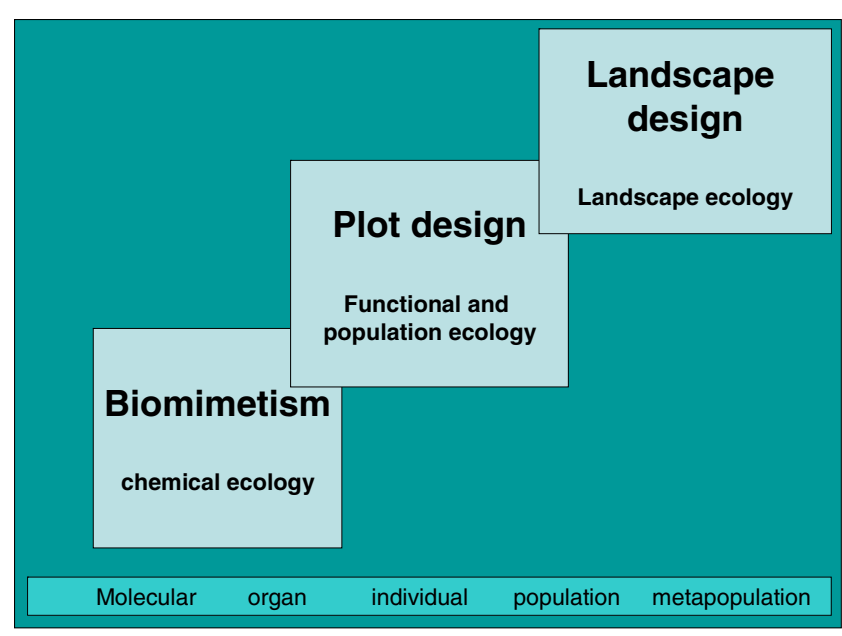

Fig. 6 The different levels of organisation for nature mimicry in agroecosystems

\subsection{Maintain soil fertility through soil cover}

Agriculture usually entails regular disturbances such as tilling and hoeing. By enabling an annual return to an identical (or at least similar) structural state, soil tillage, one of the practices at the origin of agriculture, can be considered as an effective way of preparing for the next crop. However, tillage does not create the same development conditions for soil-borne species as techniques that do not disturb the soil through mechanical action (Neher and Barbercheck 1999). The soil fauna and flora (micro, meso, and macro) are deeply modified in tillage systems compared to no-tillage systems. Soil-borne biodiversity appears to be greater when there is no soil tillage, in relation to the large quantities of residues and organic matter returned to the soil in no-tillage systems. Soil tillage is thus a man-made disturbance that modifies the dynamics and balance between animal and plant species (weeds, earthworms, etc.).

\subsection{Favour facilitation vs. competition between plants}

In plant combinations, various rhizosphere processes may be involved in helping to increase the performance of intercropped species: one of the species (sometimes both) facilitates access to nutrient resources that are little available to the associated cultivated species. In that way, among the facilitation phenomena, nutritional interactions between species can be encouraged. Combinations including nitrogen-fixing legumes are, of course, among the best known and the most efficient. For instance, legumes can provide other species with large quantities of nitrogen through their dead roots or nodules. Under certain conditions (nitrate-rich soils), the 
legume-combined with a cereal competing for that resource-may fix more nitrogen than in a legume monoculture situation.

\subsection{Contain pests through complex trophic levels}

The intensity of pest problems faced by modern agriculture lies behind the massive use of chemicals. It is now well-documented that the extreme simplification of crop monocultures generates drastic epidemic pest problems due to the absence of biological regulation, leading to decreases in crop productivity and ecosystem sustainability. There is a great deal of evidence that biodiversity in plant communities, a fundamental characteristic of natural ecosystems, might be used in agroecosystems to improve pest management.

Crop protection is thus a particularly rich field for application of the mimicry theory: it is a matter of reconstructing the trophic networks operating in natural ecosystems to provide more effective control of crop pests. It calls for a change in paradigm, switching from a "curative and focalized" vision to a "preventive and systemic" vision. The approach consists in promoting habitats that are suitable for the native useful fauna and unsuitable for harmful fauna (Ratnadass et al. 2011).

Plant composition and structural organisation on a field and landscape scale may have direct or indirect effects (via auxiliaries) on most herbivore pests. By favouring an abundance of associated natural enemies, plant diversity may improve the regulation of insect herbivore populations.

Effects include push-pull mechanisms that require a precise assemblage of plant species. Push-pull procedures are based on using a set of stimuli emitted by plants that modify the behaviour of insects. The strategy consists in reducing pest populations by repelling them or discouraging them from coming to settle on threatened plants, or by attracting them to other neighbouring plants. The stimuli may be visual, chemical, or foodbased. For instance, pigeon pea (Cajanus cajan), maize, or gombo (Ablmoschus esculentus) are able to attract the species Helicoverpa armigera, a cotton and tomato pest (Pike et al. 1987 quoted by Deguine et al. 2008). Bottom-up type push-pull properties can be applied in top-down type actions by encouraging the development of auxiliaries. The installation of weedy strips favours the development of auxiliary organism populations, by increasing nectar and pollen nutrient resources for numerous insects (Wackers et al. 2007 quoted by Deguine et al. 2008). Many intercrops have also been tested as trap plants with various crops. For instance, the use of alfalfa or sorghum with cotton has been widely developed in Australia and the USA (Deguine et al. 2008).
In natural ecosystems, pest populations are usually regulated by polyphagous predators. Encouraging that functional group, through the installation of suitable habitats, is a new avenue.

\subsection{Use plant properties and biological alternatives} to control pests

Biopesticides and botanicals can also serve as alternatives to chemical pesticides. Microbes and natural plant extracts can serve as direct natural alternatives to pesticides. The fungus Metarhizium anisopliae var. acridum has proved to be effective against locusts and grasshoppers, and has even been developed into a commercial product by IITA-Benin (IITA 2008). Other sub-species of $M$. anisopliae have been found to be effective in termite control (Su and Scheffrahn 1998) and other fungi, such as Beauveria bassiana, have proved efficient in controlling diamond back moth and banana weevil (Grimm 2001), and Neozygites tanajoa is effective against cassava green mite (Delalibera and Hajek 2004).

Insecticidal and/or repellent properties may come from botanicals: studies have shown this for extracts from leaves of the African mint Hyptis sualovens, papaya, and neem.

\subsection{Reproduce ecological successions after disturbance}

By studying the more or less regular disturbances in ecosystems, ecology provides models that help to understand how the specific composition of such ecosystems evolves. The successions of species seen after a disturbance have been covered in numerous studies. Far from being stable and unchangeable, natural ecosystems are subject to major dynamics that need to be considered here. According to Walker et al. (2004), ecosystem dynamics can be described and analysed in the form of a cycle, which can be broken down into four successive phases: a growth phase $(\mathrm{r})$, then conservation $(\mathrm{K})$, followed by senescence $(\Omega)$ then reorganisation $(\alpha)$. Phases $\Omega$ and $\alpha$ form a loop that leads to a new phase $r$ that is either similar to or different from the previous one. Each of these phases corresponds to plants with different characteristics. Plants of the $r$ type, productive, colonising, adapted to open environments, are followed by plants of the K type, adapted to more competitive environments for more scarce resources. Fecundity, precocity, and productivity oppose plants of the $\mathrm{r}$ and $\mathrm{K}$ type. Application of this theory of adaptive cycles to agrosystems, and more precisely to cropping systems, is worth particular attention and may prove useful for understanding and interpreting the dynamics of certain cropping systems. Hypotheses could thus be put forward as to the duration of phase $\mathrm{K}$ in a cropping system, the 
determinants of phase $\Omega$ or the opportunities offered during phase $\alpha$ for more effectively understanding the dynamics and sustainability of these cropping systems. However, the existence of phases $\mathrm{r}, \mathrm{K}, \Omega$ then $\alpha$ do not necessary mean the completion of a cycle: moves from $\mathrm{r}$ to $\Omega$ or even moves from $\alpha$ to $\Omega$ (opposite direction) are theoretically possible, all the more so in systems under human control, and they need to be analysed. Traditional slash-and-burn systems in the humid Tropics provide an enlightening example here (Wood and Lenné 1999): after the destruction of forest by fire, grain crops are planted (rice, maize, etc.), soon followed by vegetatively propagated plants (cassava, taro, yam, banana), soon intercropped with or replaced by woody perennial species (fruit trees, palms, coconuts). Grain cropping is followed by vegetable cropping, followed by sylviculture, ultimately recreating a forest cover. Shifting agriculture in the Tropics consists of alternative periods of fallow and cultivation. During the fallow period, successional vegetation takes place during soil restoration and may diversely be used, managed, exploited, or harvested depending on the site and climate. The main objective of fallow is to restore chemical and biological soil fertility. It allows the replenishment of nutrients, decreases populations of weeds and pathogens, increases the population of earthworms and mycorrhizal fungi.

\section{A framework for action}

\subsection{The three steps}

Methodologies for designing cropping systems from Nature have been proposed by several authors. Raintree (1987) proposed methods for agroforestry diagnosis and design in developing countries, mainly summarising ICRAF's efforts. Hobbs and Morton (1999) identified a set of steps required for the development of agricultural systems based on mimicking natural ecosystems. These steps include the identification of functions to be improved and of key species in natural ecosystems that fulfil those functions.

A framework is proposed here to establish a methodology for the construction of cropping systems built from observations of nature (Fig. 7). It can be divided into three main steps:

The first step is to observe natural ecosystems in the area in question, if any are left. This means identifying not only species but also the functional characteristics of the vegetation to be mimicked, and the main biological interactions existing between plants and animals in these ecosystems. This knowledge may be difficult to acquire in some situations, given the complexity of natural ecosys-

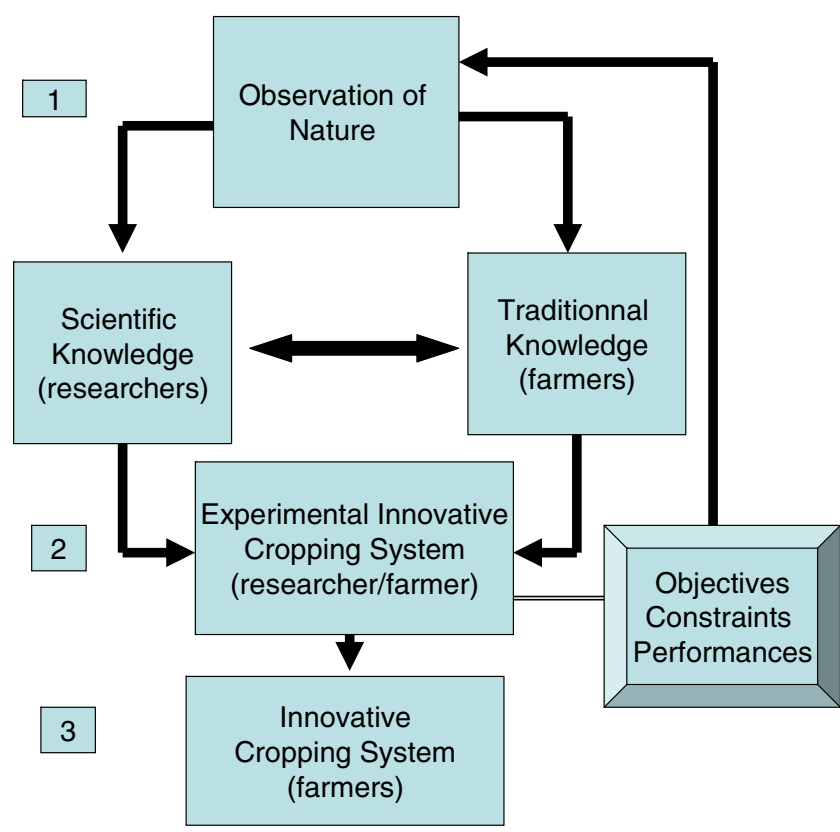

Fig. 7 A three-step framework for designing cropping systems from nature

tems. Setting up new agroecological practices mimicked from nature requires specific scientific knowledge based on a holistic and multidisciplinary approach involving and integrating expertise in systemic agronomy, ecophysiology, plant protection, botany, and ecology. This step requires ecological knowledge of local natural ecosystems, along with an analysis of the objectives sought for the cropping system. Local farmers are also often a source of original agroecological knowledge based on observations of nature. This traditional knowledge should be transformed into scientific knowledge requiring a multidisciplinary approach between biophysical sciences (agroecology) and social sciences (ethnobotany). Such traditional knowledge from local farmers is often directly integrated into existing and/or new cropping systems.

Step 2 consists in setting up experimental cropping systems based on the knowledge established in step 1 and on the objectives of the cropping systems. It needs to answer the following questions:

1. What levels of performance and services do existing cropping systems fail to achieve?

2. What levels of performance and services should the novel design achieve?

3. What life-forms are required (based on the natural system analysis in step 1)?

4. What species are needed?

5. What arrangement of species can be proposed, both in space and time, considering targeted performance levels? 
Designing cropping systems from nature requires the use of specific practices or combinations of practices on a field scale, in order to enhance the appropriate ecological functions at a given site, for given objectives. These practices include mixed cropping of species, varieties or cultivars, intercropping, rotations, agroforestry practices, cover crops, service plants, no-tillage practices, composting, and green-manuring. All these techniques might be combined in a variety of more or less complex combinations. But their success and their development also depend on how well farmers can incorporate these practices in new cropping systems that satisfy both ecological, economic, and social constraints on a farm scale (step 3).

\subsection{The need for participatory approaches}

Participatory approaches are necessary at each step of this framework, (1) to understand traditional knowledge of local ecosystems, (2) to integrate it into new cropping systems that are understandable, useful, and acceptable to other farmers. The main challenge is not only to design systems that are sustainable from an ecological point of view, but also according to economic and social criteria, in order to be adopted by numerous farmers. There is abundant scientific literature on farmers' adoption of innovations, and cropping systems designed from nature are to be considered as other innovative systems in that regard. Even if resource conservation is a strong motivation for designing cropping systems from nature, adoption will of course be highly dependent on economic considerations. New systems must be profitable, including the costs of establishment and of long-term maintenance. For example, the no-tillage principle has given rise to new cultural practices that are now widely used in the USA, Canada, Australia, or even Brazil; these practices consist in maintaining the soil under a biological mulch cover at all times and not tilling it, as in natural ecosystems. This set of techniques, sometimes called conservation agriculture, has provided some real solutions to the problem of soil erosion under certain conditions. Indeed, in some cases, it enables better soil conservation (reduced erosion), and modifies (intensifies) the biological activity of soils and their structure, thereby helping to stabilise and increase yields, and certain environmental services (such as increasing carbon sequestration in the soil, reducing the use of fossil fuel energy). Despite their apparent advantages, these direct-seeding techniques are not very widely used for the moment in Europe (Holland 2004) and in small-scale tropical agriculture, for biophysical, technological, organisational and institutional reasons (Erenstein 2003; Giller et al. 2009). The introduction of trees in a system is another example of a major structure modification that may generate new costs. Moreover, systems designed from Nature may be highly complex, not only from a biological point of view but also, and mainly, because of the specific knowledge they call for, and the specific characteristics they may require in management terms. Constraints that might obstruct other farm activities have to be considered, such as limitations in the use of agricultural machinery or livestock movements. Pannel (1995) identified the list of factors that influence the profitability of legume-based dryland farming systems in areas with a Mediterranean climate in Australia. Factors included short-term profit factors (yields and costs), short to medium-term factors (nitrogen fixation by legumes, weed control, disease dynamics, etc.), sustainability factors (such as herbicide resistance or pasture legume persistence), risk factors (such as yield and price variability and covariance), and whole-farm factors (such as machinery capacity, finance and labour availability and cost, etc.). Whole-farm factors also include the farmer's knowledge and experience, certainly a significant factor for mimic cropping systems from Nature.

From a social viewpoint, the multiple sources of income or services (wood, pharmacopoeia, gathering, hunting, climatic protection, limitation of nitrate losses, landscape, fire protection, etc.) offered by agroforestry systems, are often a major stability factor. This makes it possible to compensate for the instability of agricultural commodity prices (case of tropical products such as coffee or copra) or the strong downward trend in structural aid (case of temperate crops). In the last 20 years, agroforestry has been gradually recognised as an efficient type of development, in both tropical and temperate zones. In the Tropics, it is a natural resource management strategy, making it possible to reconcile agricultural development and the need to conserve soil, water, the local and regional climate and, more recently, biodiversity (Gascon et al. 2004; Götz et al. 2004). In temperate zones, these advantages remain valid, but agroforestry is also a strategy for diversifying specialised farms, helping to more effectively conserve the rural environment, and providing a source of quality timber which is currently in very short supply (Dupraz and Capillon 2005). The prospects for developing agroforestry systems in temperate and Mediterranean agricultures are considerable today, particularly in Europe (Eichhorn et al. 2006).

\section{Conclusion}

Given the health status of agrosystems worldwide and their impact on ecosystems in general, it is fair to say that it is urgently time to explore new pathways for agriculture. Rediscovering the benefits of nature-like ecosystems when designing cropping systems may be one of those pathways. More generally, it seems clear today that agrosystems need to be re-examined taking the knowledge and paradigms of ecology into account. Ecologists, more than agronomists, 
have indeed shown an interest in the functions and the role of species in ecosystems. It would therefore be worthwhile for agronomists to take another look at the coexistence of competing species in a fluctuating or spatially structured environment, the creation of spatial heterogeneity by the organisms themselves, or the permanence of dynamics that are far from balanced, which are studied by ecologists, especially in forest ecosystems, in order to design sustainable agrosystems. More than ever, the new challenge facing agriculture remains the trade-off between productivity and resilience, a trade-off whose limits are a choice and a responsibility for society, hence ultimately an ethical choice. This new challenge means finding local solutions from natural local trajectories, and requires the development of new tools mainly inspired by ecology. The overall objective, for a local society, becomes to guide the trajectories of ecological systems as a function of the project it has constructed (Blandin 2009). It is possible that nature will not give us the whole set of acceptable solutions, but we believe natural ecosystems may inspire us to produce sustainable patterns. As shown in this paper, agroecosystems can evolve gradually from natural ecosystems, such as humid agroforestry systems or parklands derived from traditional tropical agriculture, but they can also be conceived from scratch, based on observations of nature and ecological concepts: reconciling ecology, agronomy and engineering has become necessary to build cropping systems for the future. These new paradigms may deeply orientate the future of agronomy as a discipline (Doré et al. 2011).

Acknowledgements I sincerely thanks all the colleagues of UMR SYSTEM and Unit HORTSYS for the fruitful discussions that are at the origin of this paper.

Open Access This article is distributed under the terms of the Creative Commons Attribution Noncommercial License which permits any noncommercial use, distribution, and reproduction in any medium, provided the original author(s) and source are credited.

\section{References}

Aerts R (1999) Interspecific competition in natural plant communities: mechanisms, tradeoffs and plant-soil feedbacks. J Exp Bot 50:29-37

Altieri MA (1995) Agroecology. The science of sustainable agriculture. London, ITP, 1987, second edition, 1995, 433p

Altieri MA (1999) The ecological role of biodiversity in agroecosystems. Agric Ecosyst Environ 74:19-31

Altieri MA (2002) Agroecology: the science of natural resource management for poor farmers in marginal environments. Agric Ecosyst Environ 93:1-24

Bergen SD, Bolton SM, Fridley JL (2001) Design principles for ecological engineering. Ecol Eng 18(2):201-210

Blandin P. (2009) De la protection de la nature au pilotage de la biodiversité. Sciences en questions, Ed. Quae., France
Brown L, Flavin C, Fench H (2000) State of the world 2000. W.W. Norton and Cie, London, ISBN 0-393-04848-9

Clergue B, Amiaud B, Pervanchon F, Lassere-Joulin F, Plantureux S (2005) Biodiversity: function and assesment in agricultural areas. Agron Sust Dev 25:1-15

Connor DJ (2001) Optimizing Crop Diversification. In: Nosberger J, Geiger HH, Struik PC (Eds) Crop Science: progress and prospects. CAB International, pp 191-211

Conway G (1998) The doubly green revolution: food for all in the twenty-first century. Cornell University Press, Ithaca

Dalgaard T, Hutchings NJ, Porter JP (2003) Agroecology, scaling and interdisciplinarity. Agric Ecosyst Environ 100:39-51

Dawson T, Fry R (1998) Agriculture in nature's image. TREE 13:50-51

Deguine JP (ed.) Ferron P. (ed.), Russell D. (2008). Protection des cultures: de l'agrochimie à l'agroécologie.Versailles, Ed. Quae

Delalibera I Jr, Hajek AE (2004) Neozygites tanajoae sp. nov., a pathogen of the cassava green mite. Mycologia 96(5):10021009

Denison F, Kiers T, West A (2003) Darwinian agriculture: when can humans find solutions beyond the reach of natural selection? Q Rev Biol 78(2):145-168

Doré T, Makowski D, Malézieux E, Munier-Jolain N, Tchamitchian M, Tittonell P (2011) Facing up to the paradigm of ecological intensification in agronomy: revisiting methods, concepts and knowledge. Eur J Agron. doi:10.1016/j.eja.2011.02.006

Dupraz C, Capillon A (2005) L'agroforesterie: une voie de diversification écologique de l'agriculture européenne? Cahier d'études DEMETER. Economie et Stratégie agricole, Paris, pp 101-113

Eichhorn MP, Paris P, Herzog F, Incoll LD, Liagre F, Mantzanas K (2006) Silvoarable systems in Europe-past, present and future prospects. Agroforest Syst 67:29-50

Erenstein O (2003) Smallholder conservation farming in the tropics: a guide to the development and dissemination of mulching with crop residues and cover crops. Agric Ecosyst Environ 100:17-37

Ewel JJ (1986) Designing agricultural ecosystems for the humid tropics. Ann Rev Ecol Syst 17:245-271

Ewel JJ (1999) Naturel systems as models for the design of sustainable systems of land use. Agroforest Syst 45:1-21

Forman RT (1995) Land Mosaics: the ecology of landscapes and regions. Cambridge University Press, Cambridge

Francis C, Lieblein G, Gliessman S, Breland TA, Creamer N, Harwood SL, Helenius J, Rickerl D, Salvador R, Wiedenhoeft M, Simmons S, Allen P, Altieri M, Flora C, Poincelot R (2003) Agroecology: the ecology of food systems. J Sustain Agr 22:99-118

Fresco LO, Kroonenberg SB (1992) Time and spatial scales in ecological sustainability. Land Use Policy 9(3):155-168

Fukai S (1993) Intercropping, bases of productivity. Field Crops Res $34: 239-467$

Gascon C, da Fonseca GAB, Sechrest W, Billmark KA, Sanderson J (2004) Bioversity conservation in deforested and fragmented tropical landscapes: an overview. In: Götz $\mathrm{S}$, da Fonseca GAB, Harvey CA, Gascon C, Vasconcelos HL, Izac A-MN (eds) Agroforestry and biodiversity conservation in tropical landscapes. Island Press, Washington, pp 15-32

Giller K-E, Witter E, Corbeels M, Tittonella P (2009) Conservation agriculture and smallholder farming in Africa: The heretics' view. Field Crops Res 114(1):23-34

Gliessman SR (2007) Agroecology: the ecology of sustainable food systems, 2nd edn. CRC Press, Boca Raton

Götz S, Harvey CA, Vincent G (2004) Complex agroforests: their structure, diversity and potential role in landscape conservation. In: Götz S, da Fonseca GAB, Harvey CA, Gascon C, Vasconcelos HL, Izac A-MN (eds) Agroforestry and biodiversity conservation in tropical landscapes. Island Press, Washington, pp 227-260

Griffon M (2006) Nourrir la planète. Odile Jacob 
Grimm C (2001) Economic feasibility of a small-scale production plant for entomopathogenic fungi in Nicaragua. Crop Prot 20 (7):623-630

Gross KL, Smith RG (2002) Incorporating ecology into agriculture. TREE 17:490-491

Gunderson LH, Holling CS (2002) Panarchy. Understanding transformation in human and natural systems. Island Press, Washington

Hatfield CB (1997) Oil back on the global agenda. Nature 387:121

Hector A et al (1999) Plant diversity and productivity experiments in European grasslands. Science 286:1123-1127

Hobbs RJ, Morton SR (1999) Moving from descriptive to predictive ecology. Agrof Syst 45:43-55

Holland JM (2004) The environmental consequences of adopting conservation tillage in Europe: reviewing the evidence. Agric Ecosyst Environ 103:1-25

Holling CS (1973) Resilience and stability of ecological systems. Annu Rev Ecol Syst 4:1-23

Hooper DU, Chapin FS, Ewel JJ, Hector A, Inchausti P, Lavorel S, Lawton JH, Lodge DM, Loreau M, Naeem S, Schmid B, Setala H, Symstad AJ, Vandermeer JJ, Wardle DA (2005) Effects of biodiversity on ecosystem functioning: a consensus of current knowledge. Ecol Monogr 75(1):3-35

IITA (2008) Integrated pest management: towards 2015. A business plan. Internal report, IITA. Cotonou, Benin

Jackson W (2002) Natural systems agriculture: a truly radical alternative. Agric Ecosyst Environ 88:111-117

Jackson L, Bawa K, Pascual U, Perrings C (2005) Agrobiodiversity: a new science Agenda for biodiversity in support of sustainable agroecosystems. Diversitas Report 4, 40 pp. Available from: www.diversitas-international.org/cross_agriculture.html

Joffre R, Rambal S, Ratte P (1999) The dehesa system of Southern Spain and Portugal as a natural ecosystem mimic. Agroforest Syst 45:57-79

Joshi L, Wibawa G, Beukema H, Williams S, Van Noordwijk M (2003) Technological change and biodiversity in the rubber agroecosystem of Sumatra. In: Vandermeer J (ed) Tropical agroecosystems. CRC Press, Florida, USA, pp 133-157

Leakey RR (1999) Agroforestry for biodiversity in farming systems. In: Collins and Qualset (Eds.) Biodiversity in agroecosystems. CRC Press: Florida. pp. 127-146

Lefroy EC, Hobbs RJ, O’Connor MH, Pate JS (1999) Agriculture as a mimic of natural ecosystems. Current Plant Science and Biotechnology in Agriculture. Vol. 37. Kluwer Acad. Pub, Netherlands

Loreau M, Naeem S, Inchausti P, Bengtsson J, Grime J-P, Hector A, Hooper U, Huston MA, Raffaelli D, Schmid B, Tilman D, Wardle DA (2001) Biodiversity and ecosystem functioning: current knowledge and future challenges. Science 294:804-808

Malézieux E, Crozat Y, Dupraz C, Laurans M, Makowski D, Ozier LH, Rapidel B, De Tourdonnet S, Valantin-Morison M (2009) Mixing plant species in cropping systems: concepts, tools and models. A review. Agron Sustain Dev 29(1):43-62

Martin JF, Roy ED, Diemont SAW, Ferguson BG (2010) Traditional ecological knowledge: ideas, inspiration, and designs for ecological engineering. Ecol Eng 36:839-849

Matson PA, Parton WJ, Power AG, Swift MJ (1997) Agricultural intensification and ecosystem properties. Science 277 (5325):504-509

Mazoyer M, Roudart L. (1997) (Eds). Histoire des agricultures du monde. Du néolithique à la crise contemporaine, Edition du Seuil, Paris

McNeely JA, Scherr SJ (2003) Ecoagriculture: strategies to feed the world and save wild biodiversity. Island Press, Washington, DC

Mitsch WJ (1996) Ecological engineering: a new paradigm for engineers and ecologists. In: Scultze PC (ed) Engineering with ecological constraints. National Academy Press, Washington DC, pp 114-132

Mitsch WJ, Jorgensen SE (2003) Ecological engineering: a field whose time has come. Ecol Eng 20:363-377

Nair PKR (2001) Do tropical homegardens elude science, or is it the other way around? Agroforest Syst 53:239-245

Neher DA, Barbercheck ME (1999) Diversity and function of soil mesofauna. In: Collins WW, Qualset CO (eds) Biodiversity in agroecosystems. CRC Press, Boca Raton, pp 27-47

O'Neill R (2001) Is it time to bury the ecosystem concept? Ecology 82 (12):3275-3284

Odum HT (1989) Ecological engineering and self-organization. In: Mitsch WJ, Jorgensen SE (eds) Ecological engineering: an introduction to ecotechnology. Wiley, New-York, pp 79-101

Pannel DJ (1995) Economic aspects of legume management and legume research in dryland farming systems of southern Australia. Agric Syst 49:217-236

Perfecto I, Armbrecht I (2003) The coffee agroecosystem in the neotropics: combining ecological and economic goals. In: Vandermeer J (ed) Tropical agroecosystems. CRC press, Florida, pp 159-194

Perfecto I, Rice RA, Greenberg R, van der Voort ME (1996) Shade coffee: a disappearing refuge for biodiversity. Bioscience 46 (8):598-608

Pike B, Rice M, Sabine B, Zalucki M (1987) The push-pull strategybehavorial control of Heliothis. Australian Cotton grower. MayJuly 7-9

Pimentel D, Hurd LE, Bellotti AC, Forster MJ, Oka IN, Schles OD, Whitman RJ (1973) Food production and the energy crisis. Science 182:443-449

Piper JK (1999) Natural systems agriculture. In: Collins and Qualset (Eds.) Biodiversity in agroecosystems. Florida: CRC Press. pp. $168-189$

Raintree JB (1987) The state of the art of agroforestry diagnosis and design. Agroforest Syst 5:219-250

Ratnadass A, Fernandes P, Avelino J, Habib R (2011) Plant species diversity for sustainable management of crop pests and diseases in agroecosystems: a review. Agronomy for sustainable development. doi:10.1007/s13593-011-0022-4

Rice R (2003) Tropical agricultural landscapes. In: Vandermeer J (ed) Tropical agroecosystems. CRC Press, Florida, pp 195-218

Sanchez PA (1995) Science in agroforestry. Agrof Syst 30:5-55

Schroth G, Lehmann J, Rodrigues MRL, Barros E, Macedo JLV (2001) Plant-soil interactions in multistrata agroforestry in the humid tropics. Agroforest Syst 53:85-102

Schroth G, Da Fonseca GAB, Harvey CA, Gascon C, Vasconcelos HL, Izac A-M (2004) Agroforestry and biodiversity conservation in tropical landscapes. Island Press, Washington

Schulte RPO, Lantinga EA, Struik PC (2002) A conceptual framework for the qualification of production stability of grassland ecosystems. Ecol Modell 159:71-99

Silver WL, Brown S, Lugo AE (1996) Effects of changes in biodiversity on ecosystem function in tropical forests. Conserv Biol 10(1):17-24

Sprugel DG (1991) Disturbance, equilibrium, and environmental variability: what is natural vegetation in a changing environment? Biol Conserv 58(1191):1-18

Su N-Y, Scheffrahn RH (1998) A review of subterranean termite control practices and prospects for integrated pest management programmes. Integr Pest Manage Rev 3(1):1-13

Swift MJ, Izac AM, van Noordwijk M (2004) Biodiversity and ecosystem services in agricultural landscapes - are we asking the right questions? Agric Ecosyst Environ 104:113-134

Tilman D, Wedin D, Knops J (1996) Productivity and sustainability influenced by biodiversity in grassland ecosystems. Nature 379:718-720 
Tilman D, Cassman KG, Matson P, Naylor R, Polasky S (2002) Agricultural sustainability and intensive production practices. Nature 418:671-677

Torquebiau E (2007) L'agroforesterie: des arbres et des champs, Paris, L'Harmattan, 150 p.. (Biologie, écologie, agronomie)

Trenbath BR (1993) Intercropping for the management of pests and diseases. Field Crop Res 34:381-405

Van Noordwijk M, Ong CK (1999) Can the ecosystem mimic hypotheses be applied to farms in African Savannahs? Agroforest Syst 45:131-158

Vandermeer J (1995) The ecological basis of alternative agriculture. Annu Rev Ecol Syst 26:201-224

Vandermeer J (ed) (2003) Tropical agroecosystems. CRC Press, Florida, USA

Vitousek PM, Hooper DU (1993) Biological diversity and terrestrial ecosystem biogeochemistry. In: Schulze ED, Mooney HA (eds) Biodiversity and ecosystem function. Springer, Berlin, pp 3-14
Wäckers FL, Romeis J, van Rijn P (2007) Nectar and pollen feeding by insect herbivores and implications for multitrophic interactions. Annu Rev Entomol 52:301-323

Walker B, Holling CS, Carpenter SR, Kinzig A (2004) Resilience, adaptability and transformability in social-ecological systems. Ecol Soc 9(2):5-24

Weiner J (2003) Ecology - the science of agriculture in the 21st century. J Agric Sci 141:371-377

Wesel A, Bellon S, Doré T, Francis C, Vallod D, David C (2009) Agroecology as a science, a movement and a practice. A review. Agron Sust Dev 29:503-515

Westman WE (1978) Measuring the inertia and resilience of ecosystems. Bioscience 28(11):705-710

Wood D, Lenné JM (1999) Agrobiodiversity: characterization, utilization and management. CABI, UK

Wu JG, Louck OL (1995) From balance of nature to hierarchical patch dynamics: a paradigm shift in ecology. Q Rev Biol 70(4):439-466 